and to remain merely an outsider; working it is true, but making the care of my own health the first and paramount. consideration.

During the course of my professional life several friends have died from a first poisoning; others have died from the second and third; others have died later from other diseases, probably induced by the poisoning. From their cases and from my own $I$ think we may draw the practical deduction that any medical man thus poisoned should, if possible, give up work for a year. I would advise him, judging from my own personal experience, to spend a summer boating and fishing in Scotland or Ireland, and a winter on the shores of the Mediterranean. If the poisoning occur a second time he should (still if possible) withdraw either entirely or partially from the active duties of the profession. In the latter case he should confine himself to such practice as will allow him to live or sleep in the country evermore. Otherwise he may expect a repetition of the poisoning, death, or disease and death; nor can he reasonably complain if it is so, for he.has had his warning.

Grosvenor-street, July, 1871.

\section{A CASE OF SALIVARY CALCULI.}

\section{Bx J. WYATT PRATT, M.R.C.S. ENG., \&e.}

L. $\mathbf{P}-$, a retired medical gentleman, aged fifty-four; has been lately in good health, but formerly exhibited indi. cations of strumous diathesis. Twenty years ago he suffered from symptoms of phthisis, and coughed up, during much bronchial irritation, several chalky concretions. Has passed, at varying intervals of a few years, without much discomfort, small single calculi from the left submaxillary duct. After three or four years' relief, on the 6th and 7 th of July last he commenced to void many small calculi from the same situation, accompanied with painful mastication and uneasiness on the floor of the mouth.

July 8th.-Has bad a bad night. At 10 A.M. he was found with both parokid, both submaxillary, and both sublingual glands much inflamed and enlarged; tonsils and uvula much increased in size, rendering deglutition very difficult, all food regurgitating into the posterior nares unless the nose was tightly held during attempts to swallow; tongue considerably enlarged, and covered with creamy fur; power of articulation almost lost; elevation at the termination of the left Whartonian duct prominent, and the duct itself distended by a small calculus, which was removed. by Dr. Edwards (my senior partner), through the natural orifice, with a probe and pair of fine forceps, after which a quantity of saliva escaped and a little bead of pus. Opposite to the left lower first molar was a transparent vesication on the mucous membrane, over the sublingual gland, upon puncturing which a quantity of clear saliva-looking fluid escaped. Skin hot; pulse full and bounding, nearly 120 ; bowels confined; both cheeks puify and much distended; breath very offensive, and saliva dribbling freely from the mouth. Ordered, two grains of calomel immediately; to inhale steam; brandy and milk diet; and twenty-five minims of chlorodyne at night.

9th.-Had a better night, and brought away two or three more calculi. A square block of white, smooth, firm lymph, as large as the crown of a molar tooth, had been secreted from the surface where the vesication had existed, and was now detached as it produced discomfort. Duct freely discharging saliva. Pyrexia diminished.

10th.- Restless night. Duct blocked up again; a blunt probe was introduced, and this had the effect of removing a little plug of sanious lymph, which was followed by a quantity of offensive pus. No calculi since yesterday. Block of lymph on the surface removed as before.

11th.-Continual discharge of healthy-looking pus from affected duct. Papilla at its entrance hard, and as large as a No. 1 shot. Block of lymph again requiring removal. Swelling reduced.

13th. - Swallows better. Left submaxillary gland still enlarged and tender; other glands diminished to natural size. Free discharge of pus. Ordered nitric acid and liberal diet.
Went on improving until the 22nd, when the largest calculus ulcerated its way through the duct, about half an inch from its mouth, and was easily removed with a pair of forceps.

From this time he progressed favourably. The fistulous opening caused by last calculus soon healed, and the discharge gradually ceased, though the floor of the mouth remained tender and irritable for three or four weeks.

The number of calculi passed during the fortnight was thirteen, varying in size from that of a good-sized pin's head to the largest, which is rather bigger than a full-sized grain of wheat, and was the only one that did not escape from the natural aperture of the gland duct. They are of a pale-fawn colour, roundish, slightly rough, and somewhat porous, and of very light specific gravity.

Wiveliscombe, Aug. 31st, 1871.

\section{CASE OF \\ ELEPHANTIASIS OF THE SCROTUM. SUCCESSFUL OPERATION.}

BY STEWART HALL HARRIS, L.K.Q.C.P., L.R.C.S.I., COLONIAI MEDICAL OFFICER, MONTSERRAT, WEST INDIBS.

Thomas H-, aged about fifty years, shoemaker, native of the West Indies, had always enjoyed good health. He stated that he first perceived swelling in the scrotum about fifteen years ago, and that some time afterwards, having applied for medical relief, on examination, it was found there existed a chronic hydrocele of the left tunica vaginalis testis, for which he hal been submitted to the radical treatment of tapping, and about thirty ounces of serous fluid drawn off, the operation apparently proving effectual. About two years after, perceiving the scrotum becoming larger, he again made application for relief, when, as he states, the usual examination was made for hydrocele, as well as the use of acupuncture needles in ascertaining the nature of the swelling, which was discovered to be elephantiasis. Nothing being done for his relief for some variable time after, he finally again consulted my predecessor, when an operation was contemplated, but not carried into effect. The swelling and hardness continued to increase up to the present time, when I found it enormously enlarged, the tumour weighing $35 \mathrm{lb}$., and reaching to the knees in the erect posture, the patient being scarcely ablo. to sustain the enormous mass.

His general health being good, I consulted my colleague with the purpose of removing the entire mass; and the date of operation being decided for the 29 th ult., every necessary was in readiness for the occasion. The previous night I gave orders for the patient to be placed on the operation table the following morning, with the tumour suspended above the level of the abdomen in a sheet, by a pulley from the ceiling, for at least two hours previous to commencing the operation, the steps of which were as follows :-

After being placed thoroughly under the influence of chloroform, I commenced by making an incision at a point corresponding to the upper margin of the symphysis pubis, and extending it along the side of the base of the tumour to the raphé in the perineum, within an inch and a half of the anus. A similar incision being made on the opposite side, and connected above and below, the skin flaps were dissected down; after which I continued to divide the fascia, and underneath this the tunica communis. I then divided the cord, and included the spermatic artery in a ligature, from thence the intervening morbid structure, until I came to the penis, which was completely buried in the mass; and after amputating it and tying the dorsal artery, rapidly continued until I came to the cord of the opposite side, after the division of which I included the spermatic artery in a ligature, and, separating the remaining adhesions, completed the operation by bringing the skin flaps together with four points of suture, and finally applied a compress and $T$ bandage. The operation lasted altogether about half or three-quarters of an hour.

The small amount of hæmorrhage which occurred was very remarkable, and took place from the spermatics and dorsal artery of the penis almost exclusively. The lats 
Mr. O'Ferrall's recominendation to suspend the tumour as in the manner done is well worthy of note as a great preventive of hæmorrbage.

July 29 th.-Evening: pulse 120 ; stomach inclined to be sick; ordered forty minims of liquor of muriate of morphia to be taken at night.

30th.-Morning: has had a tolerably good night; pulse 110 ; complains of slight pain in the stomach. Evening: pulse 100; pain has left the stomach, and he has taken nourishment freely during the day.

August 1.st.-Pulse still 100; has had a good night's rest, and feels much better; takes his nourishment freely.

The patient progressed favourably from day to day, the sutures being removed on the sixth day without the least hæmorrhage following. A very small portion of the wound healed by the first intention, the remainder having granulated; the wound was syringed morning and evening with carbolic-acid lotion.

Plymouth, Montserrat, West Indies, Sept. 7th, 1871.

\section{A CASE OF TRIPLE COMPLICATION OF LABOUR.}

BY CHAS. HAMMOND, M.R.C.S., L.R.C.P.L.

ON the 14th June, at 11 A.M., a messenger came to me to see Mrs. A-, residing four miles distant. I was away from home on a long round, and did not return until 5 P.M. The patient, aged thirty-nine, had been in labour with her eighth child since 1.30 A.M. ; and a midwife had been called, who advised them to send for me, and departed. When I entered the room I was much struck with the cadaverous appearance of the patient, and ordered brandy. On making an examination, $\mathrm{I}$ found the placenta presenting, which was easily removed. On inquiry, I was informed that there had been no unusual bæmorrhage. I then administered ergot and brandy. As there were no pains, and as none followed after a reasonable time, I conmenced turning, and gave more brandy. Still no pains followed, but the patient rapidly sank, and died within two hours after my arrival, before the delivery was completed.

I bad sent for assistance to Mr. Curtis, of Alton, but be did not arrive until after the patient died.

On careful inquiry we could not find that the patient had sustained any notable shock, nor had the friends observed anything very unusual.

Mr. Curtis and I agreed to extract the fotas, but found this impossible without perforating the liead, when a gush of serum followed, which enabled the extraction to be completed and disclosed a very large hydrocephaius.

On the following day we made a post-mortem examination, when, on cutting down on the uterus, it was found to be the size of an adult head; the walls were about an inch and a half thick, with a rupture about six inches long, extending downwards on the posterior side and through the os.

The patient had fallen down on more than one occasion during her premnancy, and hurt herself severely six weeks before, for which I had attended her. Mr. Curtis suggested, in explanation of the extensive rupture unaccompanied by notable shock, that the fall had injured the uterus, rendering it liable to rupture; that the rent had been small at first, and had extended with each pain.

Bentley, July, 1871.

Parasitic Uiseases of THe Scalp. - To destroy the parasites, Küchenmeister advises the use of alcohol, which retards the development of the sporules. It has, however, been shown that the alcohol does not reach the follicles. Tincture of iodine is more efficacious, but its use must be kept up at least three months, even in the most favourable cases. Prof. Von Erlach, of Berne, applies oil of turpentine with a camel's-hair brush, and maintains that this application is more certain of success than all others, and requires less time than the generality of aprlications. He states that he succeeded in curing porrigo decalvans in fifty days, and several cases of sycosis in a week.
A eftlirtor

OF THE PRACTICE OF

\section{MEDICINE AND SURGERY IN TIR HOSPITALS OF LONDON.}

Nulla autem est alia procerto noscendi via, nisi quamplurimas et morborum et dissectionum historias, tum aliorum, tum proprias collectas habere, et inter se comparare.-BIongagir De Sed. et Caus. MLorb., lib. iv. Procmium.

\section{MIDDLESEX HOSPITAL.}

TWO CASES OF CLEFT PALATR.

(Under the care of Mr. HuLkE.)

We are indebted to the house-surgeon, Mr. Davidson, for the notes of these cases.

Cleft of the Soft Palate; Staphyloraphy, under chloroform, with Smith's gag.-A little girl, two years and a half old, was operated on, under the influence of chloroform, by Mr. Hulke, with the aid of Smith's gag. The levatores palati were divided after Fergusson's method. There was but little bleeding, and no sickness. For abont a week the case did well; and then, in a fit of coughing, the sutures were torn out, and the cleft was reopened. Thirteen months after the first operation Mr. Hulke operated again; using, on this occasion, silkworm-gut sutures instead of the ordinary ones of spun silk. On the fourteenth day two of the stitches, and on the nineteenth the remaining ones, were removed. 'There was perfect union throughout the entire length of the cleft.

Cleft in the Soft and Hard Palates; Staphyloraphy after Sis. W. Fergusson's method, and uranoplasty after Langenbeck's.A girl, seventeen years of age, was admitted with a cleft dividing the velum and also the hard palate as far forwards as the position of the incisive foramen. The maximum breadth of the cleft in the hard palate was half an incb, and the sides rose steeply from the alveolar border. For a few days the patient tickled the roof of her mouth with a feather, with the result of greatly diminishing its sensitiveness. Mr. Hulke united the balves of the velum by staphyloraphy. The great self-control of the patient enabled him to complete the operation in much less time than it usually occupies. The hinder part united immediately; but the front stitches were dragged out, and at this part a slight ulceration arose, which soon bealed without doing much damage. Four months later MTr. Hulke closed the cleft in the hard palate, detaching the periosteum with the mucous membrane from the bones, as recommended by Langenbeck, by means of elevators, and separating the upper border of the velum from the posterior margin of the palatine process of the palatine bone. The flaps so made came readily together, and perfect union resnlted, excepting at one point where a minute cipillary averture remained. When recently seen (two months after the second operation), the voice had greatly improved.

\section{UNIVERSITY COLLEGE HOSPITAL.}

\section{REDUCTION OF OBESITY PREPARATORY TO OPERATION.}

(Under the care of $M_{r}$. Bermente HiLL.)

TrE patient is the subject of a reducible inguinal hernia. $\mathrm{He}$ is a blacksmith by trade, and a man of active habita; though endowed with a well-developed muscular system, he suffers from extreme obesity, in consequence of which all attempts to control the hernia by means of trusses have failed. He is five feet nine iuches in height, and weighed, on admission, eighteen stone six pounds. It is proposed to adopt Lister's antiseptic operation for the hernia, but, as a preparatory measure, an effort is being made to reduce the excessive deposit of adipase tissue. His diet consists of six ounces of meat with greens or turnips ad iijitum for dinner; and tea without milk, though slightly sweetened, with bran biscuits, for breakfast and tea. In his desire to hasten the object in view, the patient usually takes no more than about two-thirds of his allowance of meat. In eighteen days he has lost seventeen pounds of weight. He professes 